\title{
照明用インバータにおける電源高調波低減対策の動向 $(3)^{\dagger}$
}

\author{
専門会員 青池 南城*
}

「照明用インバー夕における高調波低減対策の動向(1)(2)」 (6月号・9 月号) に続き, 最終回では「最近の動向」に ついて述べる。

\section{1. 高調波低減技術の最近の動向}

これまで見てきたように，アクティブフィル夕は電子安 定器を構成する主インバー夕に，もう一つ余計にインバー 夕を加えた形になっており，変動効率の低下やコストアッ プ，さらには形状重量が大きくなる。一方，高調波抑制の ためとはいえ，アクティブフィル夕をただ単純に付け足す だけで良しとするのは安易過ぎはしないか，という考え方 がある。

これらの問題点を払拭する目的でインバー夕本体が高調 波低減の機能を兼ね備之た機能を持つ，いわゆる複合形の 電子安定器の研究開発が活発に行われている。ここでは各 種学会などで発表されている論文を基に，複合形電子安定 器の動向について述べることとする。

複合形電子安定器は種々提案され，各方式毎に定まった 名称は定着していない，実用化の進展とともに定着してゆ くものと思われる。ここでは，説明の都合上，適宜名称を 付して説明する。

\section{（1）ディザー整流方式}

図15は，ディザ一方式として提案された回路方式であ る ${ }^{9)}$. 電源電圧 $\mathrm{V}_{\mathrm{S}}$ が正の半サイクルの場合 $\mathrm{FET}_{1}$ がオンす ると, $\mathrm{L}_{1}, \mathrm{D}_{1}$ を介して電源を短絡するので，入力電流は増 加する。 FET オフまたは $\mathrm{FET}_{2}$ オンでは $\mathrm{L}_{1}$ に蓄積された エネルギーが $\mathrm{V}_{\mathrm{S}}$ に重畳され， $\mathrm{D}_{1}, \mathrm{FET}_{2}$ を介して平滑コン デンサ $\mathrm{C}_{1}, \mathrm{C}_{2}$ に放電し, 入力電流は減少し, 鋸歯状波電流 が流れる。このコンデンサの鋸歯状態電流を低減通過フィ ル夕 $\mathrm{L}_{0}, \mathrm{C}_{0}$ で電源 $\mathrm{V}_{\mathrm{s}}$ と略相似の電流波形を得て高調波を 低減する.同時に $\mathrm{FET}_{1}, \mathrm{FET}_{2}$ の交互のオン, オフによっ て共振回路 $\mathrm{L}_{2}, \mathrm{C}_{4}$ の働きによってランプ回路に高周波電流 を供給する。この回路は，比較的簡単な構成で高調波を抑 制できるとともに，回路効率の低下が少ない特徽がある.

\section{(2) 複合形電流共振形インパータ方式}

図16は負荷に電力を供給するインバータとして電流共振 形インバー夕を構成している ${ }^{10)}$. スイッチ $\mathrm{Q}_{2}$ オン時に $\mathrm{L}_{1}$

$\dagger$ A Trend of Methods for Reducing Input Current Harmonics in Electronic Ballasts (2)

*東芝ライテック蛛研究所 Nanjou Aoike

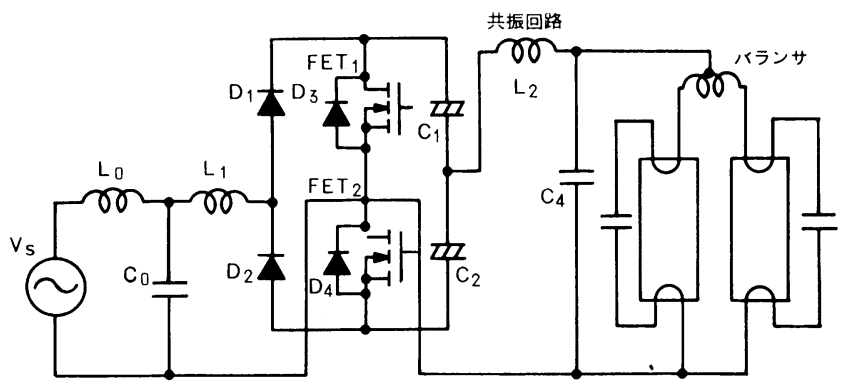

図15 ディザー整流方式

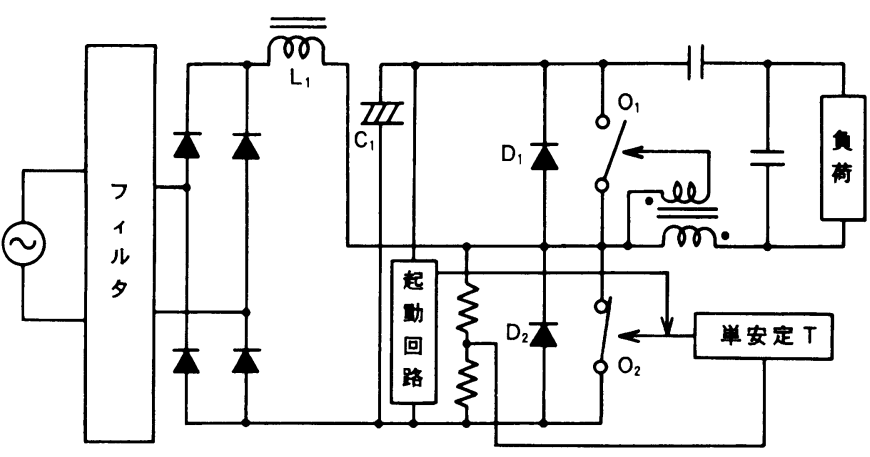

図16複合形電流共振インパータ方式

に蓄積されたエネルギーを $\mathrm{Q}_{2}$ オフ時にダイオード $\mathrm{D}_{1}$ を介 してコンデンサ $\mathrm{C}_{1}$ に充電する構成とし，コンデンサ $\mathrm{C}_{1}$ の 電圧が直列インバータの入力電圧となる。いわわスイッ チ $\mathrm{Q}_{2}$ を昇压チョッパ形アクティブフィル夕用スイッチと 兼用したものである。

\section{（3）複合形部分平滑共振方式}

図17がRPF 方式として提案された回路である ${ }^{111}$ 。基本 構成は図 6 (b)の部分平滑方式を採用している。高調波低減 の考之方は困 $6(\mathrm{~b})$ の部分平滑コンデンサ $\mathrm{C}_{3}$ への電源から の電荷充電区間は同図に示した入力電流が流れるが， $\mathrm{C}_{3}$ の 放電区間に入力電流がゼロにならないようにしたものであ る.困17において, 部分平滑コンデンサ $\mathrm{C}_{3}$ の放電区間でも 電源からインバータにエネルギーが供給されるように，小 容量のコンデンサ $\mathrm{C}_{1}, \mathrm{C}_{2}$ およびダイオード $\mathrm{D}_{1}$ を付加して いる、 $\mathrm{C}_{3}$ の放電区間では，一石式インバー夕の共振により $\mathrm{Q}_{1}$ オフ時に $\mathrm{C}_{3}$ から $\mathrm{L}_{1}$ を経由して $\mathrm{C}_{2}$ が電源電圧を超える 電圧に充電される。 $\mathrm{Q}_{1}$ オン時の最初は $\mathrm{C}_{2}$ の電荷によっての みインバー夕にエネルギーが供給され，時間とともに $\mathrm{C}_{2}$ の 電荷はなくなり $\mathrm{D}_{1}$ がオンして $\mathrm{C}_{1}$ の電荷が供給され，この とき入力電源から入力電流が $\mathrm{C}_{1}$ に充電される. その結果, 電源電圧に相似な入力電流が流れ高調波は低減する. 


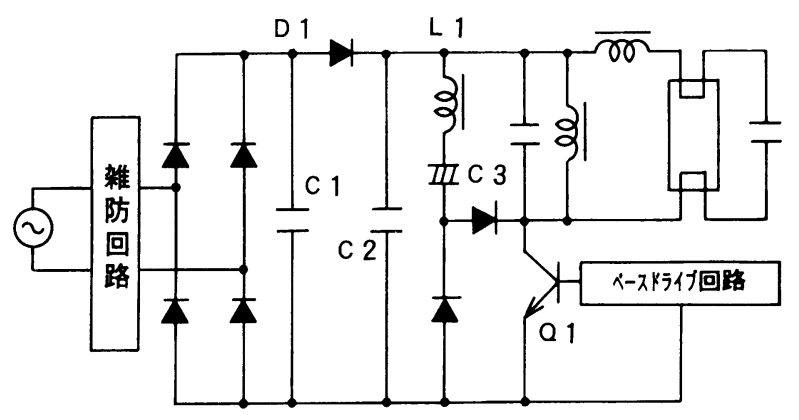

図17複合形部分平滑共振方式

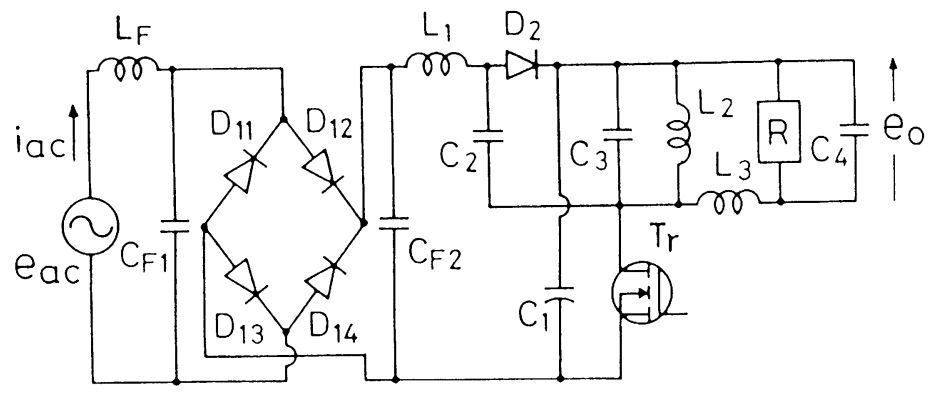

図18複合形電圧共振インバータ方式

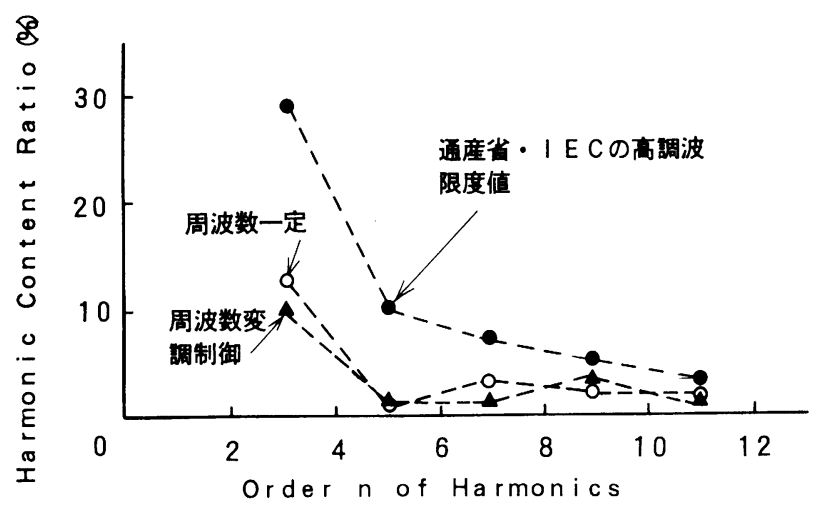

図19 入力電流歪率特性

（4）複合形電圧共振インバータ方式

図18は筆者などが検討している複合形電圧共振インバー 夕方式である121.この回路はノイズフィルタとしてのイン ダクタ $\mathrm{L}_{\mathrm{F}}$, キャパシタ $\mathrm{C}_{\mathrm{F} 1}, \mathrm{C}_{\mathrm{F} 2}$, アクティブフィルタ用と しての $\mathrm{L}_{1}$, ダイオード $\mathrm{D}_{2}$, 平滑コンデンサ $\mathrm{C}_{1}$, 並列共振 回路としての $\mathrm{C}_{3}, \mathrm{~L}_{2}$, バラストチョーク $\mathrm{L}_{3}$, 蛍光ランプ尒 熱用コンデンサ $\mathrm{C}_{4}$, 主インバータ用スイッチとアクティブ フィルタ用スイッチを兼用するスイッチ $\mathrm{T}_{\mathrm{r}}$ 抢よびアクテ イブフィルタ部分とインバー夕部を接続するキャシタ $\mathrm{C}_{2}$ からなる， $\mathrm{C}_{1}$ の電圧が主インバー夕への入力電圧となる.

この方式は共振形インバータにキャパシタ $\mathrm{C}_{2}$ を採用し
たところに特長があり，他の回路部品定数との関係を適切 に選定することにより, 簡単な構成で低高調波, 高力率化 できる特長がある。 $\mathrm{C}_{2}$ の代わりにダイオード使用した場合 と異なり，主トランジスタがゼロ電圧スイッチングが容易 で軽負荷時における電圧上昇を軽減する効果がある。この 回路の動作は $\mathrm{L}_{1}$ の選択により，その值を大きくとったりア クトル電流連続モードと, 小さくとった不連続モードの 2 つに分けられる。高調波低減, 高力率化, 回路素子の小形 化や，特に主パワートランジス夕の電圧ストレス低減の観 点からは不連続モード，または連続モード直前の境界モー ドで動作することが有利である。図19に主トランジス夕の スイッチング周波数を $45 \mathrm{kHz}$ 一定の場合と, 周波数変調を した場合についての高調波の含有率を，通産省のガイドラ インおよびIEC1000-3-2の勧告值と比較して示した。いず れの場合もその限度值を下回っている.

\section{2. 結び}

インバー夕式蛍光灯器具を通産省のガイドラインに整合 させる低減手段としては，今のところ昇压チョッパによる アクティブフィル夕が沉用的に使用されている。この方法 は万能であるが，電力損失の上昇，コストアップ，形状重 量が大きくなることが奬念される。この問題の解決のため に，昨年，通産省の高調波抑制ガイドラインの提示を前後 して，インバータ本体がアクティブフィルタの作用を兼ね 備える複合形のインバータの研究開発が活発化している. 特に, 住宅用照明器具に通産省のガイドラインが適用され る1998年以降, ぞのような方式が主流になるかは今後の研 究開発にかかっている。しかし，概赫アクティブフィル夕 方式と複合形インバータ方式の双方が照明器具の機能に応 じて使い分けられるものと考之られる。

\section{参 考 文 献}

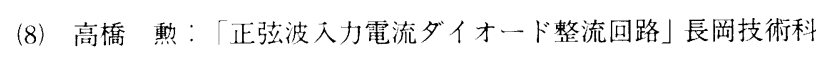
学大学 $(1994-9)$

（9）高橋, 竹内，三谷：「入力力率良好な高周波変換用コンバー夕」 平成元年度電気学会全国大会論文集 $5-41$

(10) 平松, 山田, 岡本, 三谷：「高調波歪を抑制した蛍光灯インバ 一夕の一検討」平成 4 年度照明学会全国大会論文集 19

(11) 乾, 杉山, 天野, 鈴木, 平岡：「蛍光灯インバー夕の高調波対 策の一検討」平成 7 年度照明学会全国大会論文集 16

(12) 松尾, 青池, 黒川, 日迫：「複合回路方式電圧共振形インバー夕の力率・歪率の改善について」電子情報通信学会技術研究報 告 PE94-6 pp.33-38 (1994)

以上 